\title{
Do You Smell Something Burning?
}

\author{
Nicky Didicher, Simon Fraser University
}

When I was a toddler, I had a security blanket; when I was seven, I accidentally burned a hole in it. I wanted to finish reading a book after I was supposed to be in bed with the lights out, so I covered my bedside lamp in the blanket to dim the light, not realizing how much heat incandescent bulbs put out and not noticing when it began to singe.

I don't remember what book I was reading, but chances are good it involved magic. Fantasy was my genre: if it didn't have magic in it, it was hard to get me interested. I did read most of the fiction in my local public library, but it was fantasy I went back to reread. I don't remember learning to read; I just remember reading every day, even in summers.

My mother read aloud nightly to her children as individuals. I felt devastated at age thirteen when she stopped reading to me in the evenings, though in retrospect I can understand that I had then three younger siblings and reading to us took up a lot of time. Later in my teens, I read aloud to my younger siblings. My mother, a Great Reader, likes realism, romance, and historical fiction, and she was able to get me interested in some of her favourites, particularly Arthur Ransome's and Laura Ingalls Wilder's children's books (which I now see as problematically racist and colonial), but I never liked Louisa May Alcott or Lucy Maud Montgomery. We could agree on E. Nesbit: historical settings for Mum and magic for me (though also the pro-British-Empire attitudes). After my father died when I was twenty-nine, each time I visited my mother we would read a book aloud to each other, taking turns with chapters. We read the whole of Naomi Novik's Temeraire series (set in a parallel Napoleonic world with added dragons) over various Christmas vacations: fantasy for me, romance for my mother.

As a teenager I expanded my reading to science fiction. At thirteen I was allowed into the adults' section of the library, having burned through most of the children's collection. I discovered that adult fantasy and science fiction were all shelved together, so I started reading that section, usually at the rate of three 
books every two weeks. My father - Engineering major, fighter pilot, Math teacher - was not a Reader, but he enjoyed science fiction and had a subscription to an SF-book-of-the-month club, and I read those, too. The first adult novel I read was Pride and Prejudice, when I was ten (I found Mr. Collins very funny), and I found I liked Shakespeare in Grade 10, so I started reading canonical literature. And murder mysteries, especially those by Dorothy L. Sayers. And a few romance novels, preferably with magic in them.

I totally never noticed that pretty much all the main characters in the books I read were white, except for Othello and Little Black Sambo... as a small child, I thought Little Black Sambo was wonderful because he was so clever and could eat so many pancakes; as a teen, I didn't think much of Othello. Sometimes there were minor characters whose skin was a different colour from mine, and I accepted the stereotypes at first and then dismissed them as stereotypes when I got to know one of the two Black students at my high school and had a guitar teacher who was from the Six Nations reserve in Brantford. However, my attitudes and assumptions were set up by all that non-critical reading as a child, and it took (and is still taking) work to unpick them as an adult. You won't be surprised to hear that, in the reading materials available to me in the 1960s and '70s, there were no overtly queer characters. Though I did notice that Janie in Harriet the Spy was not interested in having male friends and wasn't very girly, it never occurred to me that Harriet was not girly, either (she seemed romantically destined for her male best friend Sport). I would have been unbelieving if you had told me that the female author of that book loved girls, not boys. I am white, female, middle-class, and cis-het, and I had a very sheltered and in many ways privileged childhood.

We didn't have much money, I never went to summer camp, and I paid for my guitar lessons after the first couple of years by babysitting and teaching beginner guitar. My mother made my clothes, and I didn't own any jeans until my aunt gave me a pair as a birthday present when I was in Grade 8. Not only did I wear noncool clothes, but I was often the smartest in my class - and got bullied for both. I learned to keep out of the corners of the schoolyard. If we'd been allowed inside the school at recess, I would have sat with a book by myself. Books were my escape from my peers. I particularly enjoyed intrusion fantasy and portal fantasy, books where we begin in ordinary reality, then something happens to push against that reality, and the overlooked, socially awkward protagonist gets to win out over the dangers and villains.

ENGL487W - Summer 2021 
Probably I subconsciously thought that magic would be the only way someone like me could be a hero, and I hotly resented the fact that the lone protagonists were boys. Girls could be part of a family encountering magic, as in E. Nesbit, P.L. Travers, Edward Eager, C.S. Lewis, and Madeleine L'Engle books, but this was before the independent girl hero in fantasy became a trope, before Lyra and Meggie and Alanna et al. I hadn't taken to Alice because I didn't get the jokes until I was an adult (and our copy had lousy reproductions of the illustrations).

Somehow, I never read the Oz books! Perhaps seeing the film version annually on television convinced me I wouldn't like them because Dorothy was frightened all the time and the magic turned out not to be real in the end (not true of the books). I wonder what I would have made of Tip, in The Marvelous Land of $\mathrm{O}_{\%}$, who is raised as a boy and then discovers she is really female and a princess? But the lack of girl heroes did not dissuade me from fantasy, which allowed me to try on lives in which I was not the teacher's pet, not the frumpy awkward sidekick.

In my middle school years, I had a best friend who was also a Reader and loved fantasy. She was, like me, a socially awkward target and outsider, but instead of just keeping out of way and being safe, [let's call her X] was belligerent, rebellious, and able to claim special creative status for herself through art. We played out fantasy stories in which she was a clever adventurous independent heroine, while I always had to be her plump, less interesting sidekick. She turned me onto reading Zilpha Keatley Snyder and some other great middle-grade authors, but I didn't appreciate the roles she assigned me in our play sessions... or some of the pranks and petty crimes she wanted me to be part of. X and I both frequented the library, but she didn't return all her books and took to stealing them when she lost her library privileges. Then she went to the library in the next town over, took out a card using my name, and I got in trouble when she didn't return all of those books, either. That was after our friendship was pretty much over already, though. I'm grateful someone wanted to be my friend in public school, but it was a bit damaging trying to be X's friend. Since then, I've had friends with whom I've shared books, but no friendship based almost entirely on books. It would be nice, but I'm OK without it. If I stay up late to finish a book now, I don't have to risk burning a blanket, and perhaps I'll email my excitement to someone who will understand.

Now I teach literature, and I often have the privilege of teaching literature that adults write for young readers. I love that part of my life. I no longer burn my way

ENGL487W - Summer 2021 
through stacks of books, except for work (but I get to read children's lit for work!). Since my work hours went up during the pandemic, I've sadly done no pleasure reading at all. When I retire, I want to read more and take a more sustained shot at writing fiction myself. And I think I'll probably write fantasy and science fiction stories that are inclusive and push against the tropes and clichés. Reading made me who I am and helped determine what I do for a living, and I celebrate the authors who helped me get there, even as I acknowledge their blind spots and damaging prejudices.

(c) (i) $\ominus$ This work is licensed under a Creative Commons Attribution-

CY NC ND NonCommercial-NoDerivatives 4.0 International License.

(C) Nicky Didicher, 2021

ENGL487W - Summer 2021 